\title{
Reducing Hyperactive Behavior Using Instrumental Classic Music on Children With Attention Deficit Hyperactivity Disorder at SLB Plus Madana Dun Ya Banjarmasin
}

\author{
Jannatul Aulia, Zulkifli, Dewi Ratih Rapisa \\ Special Education Study Program, Faculty of Teacher Training and Education \\ University of Lambung Mangkurat \\ Banjarmasin, Indonesia \\ jeaulia.ja@gmail.com
}

\begin{abstract}
Based on the fact discovered at Sekolah Luar Biasa (SLB) Plus Madana Dun Ya Banjarmasin, it is found that there is a child with an Attention Deficit Hyperactivity Disorder (ADHD). This child has excessive hyperactivity, especially in sitting quietly and moving aimlessly. The objective of this study is to find whether there is a reduction in the hyperactive behavior of children with ADHD by using instrumental classical music. This research employed a Singel Subject Research (SSR). The design used in this study was A-B-A with two behaviors studied. The AB-A design has three stages namely the baseline stage 1 (A1) as a stage before giving treatment, the intervention stage $(B)$ when the instrumental classical music is played, and the baseline stage 2 (A2) as the final stage in which the child is not given any treatment to know the influence when given intervention. The data recording system used in this study was duration. The research subject in this study was a child at SLB Plus Madana Dun Ya Banjarmasin with two behavioral targets to be analyzed, namely the difficult behavior of sitting quietly and moving aimlessly. The results show that listening to instrumental classical music can reduce hyperactivity by reducing the duration of difficulty sitting quietly and moving aimlessly on children with ADHD. The reduced behavior of difficult to sit quietly can be seen from the decrease in the duration of time from 7 minutes to 4 minutes. The moving aimlessly behavior can be seen from the duration of time from 6 minutes to 4 minutes. It can be concluded that there is a reduction in hyperactivity behavior by using instrumental classical music
\end{abstract}

Keywords-hyperactive behavior; instrumental classical music; ADHD.

\section{INTRODUCTION}

Government defines special education as stated in Article 32 paragraph (1) of Law Number 20 of 2003 concerning the National education system, as follows: "Special education is education for students who have difficulty following the learning process due to physical, emotional, mental, social, and/or have the potential for special talent intelligence ". Smith et al., (1975 ) in reference [1], explain that the term "pendidikan khusus" or "pendidikan luar biasa" is translated to "special education". In the early 1970 s, special education is defined as a profession intended to manage educational variables to prevent, reduce, or eliminate conditions that result in significant disturbances to the functioning of children in academic, communication, locomotor, or adjustment fields, and children who are targeted are called exceptional children in other words "children with special needs".

Problems that are often encountered in children with special needs are difficult to focus attention, difficult to manage, unable to be quiet, and often restless. These children usually experience impaired attention and hyperactivity known as Attention Deficit Hyperavailability Disorder (ADHD). In general, ADHD is a condition when a person shows symptoms of lack of concentration, hyperactivity, and impulsivity which cause an imbalance of most of their life activities [2]. Attention Deficit Hyperavailability Disorder is a developmental disorder in the form of increased motoric activity of children to cause children's activities that are unusual and tend to be excessive. Children with ADHD experience hyperactivity behavior disorders that causes them difficult to control their behavior because they like to do things according to their will. Stimulation or external activities causes these children to often leave their seats during the teaching and learning processes. The results of observations conducted at SLB Plus Madana Dun Ya Banjarmasin showed that there is one child ADHD experiencing hyperactive behavior disorders. This ADHD child has a difficult behavior sitting quietly and has no purposeful movement.

Various alternatives to deal with the hyperactivity behavior of children with ADHD have been found by experts. Among them are behavior modification media (behavioral therapy), handling drugs, nutritional media, playing media, and music media. One interesting alternative is music media. The method of music therapy is one way to overcome changes in hyperactivity behavior of children with ADHD. Psychologically, music can make a person relax, reduce stress, create a sense of security and prosperity, release feelings of sadness and joy, and help in releasing a sense of stress [3]. 
Music-making has an effect on brain and cognitive development, so that the music is potential as a rehabilitative and restorative therapy of brain dysfunctions [4]. It is the Sensory Motor Rhythm (SMR) as a brainwave that can make people focus or concentrate. If someone does not produce this wave, he/she will automatically not be able to concentrate, and the Attention Deficit Hyperactivity Disorder (ADHD) is one example. Therefore, the objective of this study is to find whether there is a reduction in hyperactivity behavior by using instrumental classical music in children with ADHD.

\section{METHOD}

This study employed a Single Subject Research (SSR). It focused on individual data as research samples. This study relates to behavior modification in children with ADHD, namely the reduction of hyperactive behavior by looking at the length of time the child sits quietly. The research design used was the design of A-B-A. The A-B-A design is one of the developments of the basic A-B design. This A-B-A design shows a stronger causal relationship between the dependent variable and the independent variable than the A-B design. When the research was carried out before the child enters the class, the child would be placed in an individual class separate from other children so as not to interfere with the activities that would be carried out. This study was carried out in Madana Dun Ya SLB Banjarmasin. The study was conducted in 16 sessions, by recording baseline data 1 (A1) for 4 sessions, intervention (B) for 8 sessions, and baseline 2 (A2) for 4 sessions. The subject of this study is a child who has ADHD disorders; therefore, the study was conducted in the form of experiments using Single Subject Research (SSR). The recording procedure was a direct observation activity carried out to record the level of the dependent variable when the event or behavior occurred. This kind of recording is the main basis of measurement in behavior modification research. There are several types of data recording using direct recording procedures, namely: recording of events, duration, latency, time intervals, and samples. The data recording system that was carried out in this study was recording duration data. The recording of duration data is the recording of how long an event or target behavior occurred.

\section{RESULT AND DISCUSSION}

One characteristic of children with ADHD is having hyperactive behavior. The particularly observed hyperactivity in this study is the child's difficulty to sit quietly. The baseline stage 1 (A1) in the first session took 7.10 minutes duration, the second session was 7.08 minutes, the third session 7.11 minutes, and the fourth session 7.13 minutes. Based on the data from baseline (A1), an average of 6.89 minutes was obtained. Obtaining data on the duration of hyperactive behavior from baseline 1 (A1) has no significant or stable changes. Schaughency \& Rothlind (1991) in reference [5] argues that the deviant behavior of ADHD children is done out of consciousness. ADHD occurs because of retardation or mental disability so that sufferers fail to behave appropriately. The fact found in the field is that children with ADHD were still difficult to regulate their behavior, especially sitting quietly which caused disruption of the learning process in school. To find out whether the hyperactive behavior of ADHD children is reduced or not, intervention was given.

The intervention stage (B) showed that there was a reduction in hyperactivity behavior on the treatment by listening to instrumental classical music with the acquisition of duration data in the fifth stage for 6.86 minutes, the sixth session was 6.65 minutes, the seventh session 6.25 minutes, the eighth session was 6.36 minutes, the ninth session was 6.05 minutes, the tenth session was 5.76 minutes, the eleventh session was 5.48 minutes, and the twelfth session was 5.25 minutes with an average gain of 6.07 minutes. At the intervention stage (B), the hyperactive behavior of children with ADHD is reduced when they were given treatment by listening to instrumental classical music. This is in line with Nurseha and Djafar (2002) in reference [6] that classical music has a function that can optimize the tempo, rhythm, melody and regular harmony so as to produce alpha waves of beta wave fiber in the eardrum while providing calmness. This is also in line with the facts found in the field that children with ADHD looked calmer than before when they were given the treatment. After being given an intervention, then the baseline stage 2 (A2) was then. This stage was given to find out whether the child's hyperactive behavior was still the same as baseline 1 (A1) or has been reduced.

The results from baseline data 2 (A2) indicated that there was a reduction in hyperactivity behavior after the intervention in the form of listening to instrumental classical music. This can be seen from the duration data obtained from the thirteenth session as long as 5.45 minutes, 5.15 minutes on the fourteenth session, 5.00 minutes on the fifteenth session and 4.68 minutes on the sixteenth session. Based on the data, the average time was 4.88 minutes. According to reference [7] the power of classical music can affect the senses, the emotional wealth they contain, and the ability to enter information both in the left and right brain that makes it a good tool for children to be able to align their minds, calm themselves, and concentrate more before, during, or after studying. Behavior is a very important aspect for someone to learn or play with other individuals. If a person's behavior is unnatural, it will interfere with teaching and learning activities or play with peers. This research is in line with reference [6] stating that music is believed to have powerful power to help a person improves learning ability, thinking, stabilizing emotions, and calming down. Therefore, there is a reduction in hyperactive behavior by using instrumental classical music.

\section{CONCLUSION}

Based on a thorough analysis, it can be concluded that there is a reduction in hyperactive behavior by using instrumental classical music on children with ADHD in SLB Plus Madana Dun Ya Banjarmasin.

\section{REFERENCES}

[1] K. Kustawan, and Meimulyani, Mengenal Pendidikan Khusus \& Pendidikan Layanan Khusus Serta Implemantasinya. Jakarta: Luxima, 2013

[2] M. Baihaqi, and M. Sugiarmin, Memahami dan Membantu Anak ADHD. Bandung: PT. Refika Aditama, 2006. 
[3] D. Djohan, Terapi Musik, 2nd ed. Yogyakarta: Galangpress, 2006.

[4] L. Rogenmoser, J. Kernbach, G. Schlaug, and C. Gaser, "Keeping brains young with making music,” Brain Structure and Function, Aug. 2017.

[5] D. Dayu, Mendidik Anak ADHD. Jogjakarta: Javalitera, 2014.
[6] Z. Ahmad, Teaching Music For Autism. Jogjakarta: Redaksi Maxima, 2015 .

[7] D. Campbell, Efek Mozart Bagi Anak-anak. Jakarta: PT Gramedia Pustaka Utama, 2002 